\title{
Research Paper: Pentylenetetrazol and Morphine Interaction in a State-dependent Memory Model: Role of CREB Signaling
}

\author{
Marziyeh Tavassoli ${ }^{1}$, Abolfazl Ardjmand ${ }^{1,2^{*}}$ (D) \\ 1. Institute for Basic Sciences, Physiology Research Center, Kashan University of Medical Sciences, Kashan, Iran. \\ 2. Department of Physiology, School of Medicine, Kashan University of Medical Sciences, Kashan, Iran.
}

\begin{tabular}{l|l}
$\begin{array}{c}\text { Use your device to scan } \\
\text { and read the article online }\end{array}$ \\
Citation: Tavassoli, M., \& Ardjmand, A. (2020). Pentylenetetrazol and Morphine Interaction in a State-dependent Memory \\
Model: Role of CREB Signaling. Basic and Clinical Neuroscience, 11(4), 557-572. http://dx.doi.org/10.32598/bcn.11.4.1482.1
\end{tabular}

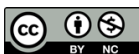

Article info:

Received: 08 Sep 2018

First Revision: 20 Sep 2018

Accepted: 15 Oct 2019

Available Online: $01 \mathrm{Jul} 2020$

Keywords:

Morphine, PTZ, CREB, Inhibitory avoidance memory; State-dependent memory

\begin{abstract}
$\underline{\text { A B S T RA C T }}$
Introduction: State-dependent (STD) memory is a process, in which the learned information can be optimally retrieved only when the subject is in the state similar to the encoding phase. This phenomenon has been widely studied with morphine. Several studies have reported that Pentylenetetrazole (PTZ) impairs memory in experimental animal models. Due to certain mechanistic interactions between morphine and PTZ, it is hypothesized that PTZ may interfere with the morphine-STD. The cyclic adenosine monophosphate Response Element-Binding (CREB) is considered as the main downstream marker for long-term memory. This study was designed to determine the possible interaction between PTZ and morphine STD and the presumable changes in CREB mRNA.

Methods: In an Inhibitory Avoidance (IA) model, posttraining morphine (2.5, 5, and $7.5 \mathrm{mg}$ / kg-i.p.) was used. The pre-test morphine was evaluated for morphine-induced STD memory. Moreover, the effect of a pre-test PTZ (60 mg/ $\mathrm{kg}$-i.p.) was studied along with morphine STD. Locomotion testing was carried out using open-field. Eventually, using real-time-PCR, the CREB mRNA changes in the hippocampus were evaluated.

Results: Posttraining MOR (7.5 mg/kg-i.p.) impaired IA memory $(\mathrm{P}<0.001)$. The pre-test injection of similar doses of morphine recovered the morphine-induced memory impairment $(\mathrm{P}<0.001)$. The pre-test PTZ impaired the IA memory recall $(\mathrm{P}<0.001)$; however, the pre-test PTZ along with morphine STD potentiated the morphine-induced STD $(\mathrm{P}<0.001)$. Alterations in CREB mRNA were observed in all groups. No difference was seen in the locomotor activity.

Conclusion: Presumably, the certain interactive effect of PTZ on morphine-induced STD is mediated through gamma-aminobutyric acid and opioid systems via CREB signaling.
\end{abstract}

\footnotetext{
* Corresponding Author:

Abolfazl Ardjmand, PhD.

Address: Institute for Basic Sciences, Physiology Research Center, Kashan University of Medical Sciences, Kashan, Iran.

Tel: +98 (31) 55621157

E-mail:ardjmand_ab@kaums.ac.ir
} 


\section{Highlights}

- Posttraining morphine impaired memory retrieval in the inhibitory avoidance (IA) model.

- Pre-test morphine recovered memory impairment and induced morphine STD memory retrieval.

- Hippocampal cyclic adenosine monophosphate response element-binding (CREB) mRNA expression dose-dependently reduced in morphine-induced amnesia, whereas, it increased in morphine STD.

- Although pre-test PTZ impaired the IA, the coadministration of pre-test PTZ with morphine STD potentiated the morphine-induced STD memory.

- Pre-test administration of PTZ decreased hippocampal CREB mRNA expression in PTZ-induced amnesia. However, pre-test PTZ treatment significantly increased hippocampal CREB mRNA expression in the PTZ-morphine coadministration group.

\section{Plain Language Summary}

State-dependent (STD) memory is a well-known phenomenon, in which the learned information can be optimally retrieved only when the subject is in the state similar to the learning state. Besides its extensive effects on daily living, STD memory can affect the human or animal performance, in particular in learning disabilities and treatment outcomes, and has implications on the effectiveness of psychological conditions. This phenomenon has been widely studied using morphine and other drugs. In the present study, the interactive effect between morphine STD and Pentylenetetrazole (PTZ) as well as the resultant changes in the pivotal role of cyclic adenosine monophosphate response element-binding (CREB), as a main molecular marker, were evaluated using a behavioral (inhibitory) model in rat. Because an individual's state (concerning morphine) may influence the impact of psychological treatment and well-being in epileptic cases to evaluate the interaction, we used PTZ for simulating the experimental epileptic conditions in lab animals. Our results revealed that in the presence of PTZ, the rats in the morphine state (morphine STD) had an augmented memory than those who were not. In addition, the observed effects were followed by coordinated alterations in CREB.

\section{Introduction}

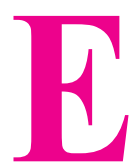

pilepsy, as one of the most common syndromes of the central nervous system, is associated with harmful cognitive and behavioral consequences (Kwan \& Brodie, 2001). Both human (Herfurth, Kasper, Schwarz, Stefan, \& Pauli, 2010) and animal (Lee, Kim, Kim, Lee, \& Lee, 2010) studies on epilepsy signify that it is accompanied by learning and memory impairments.

Clinically, the cognitive impairments in epilepsy can be classified into permanent (stable /long-lasting), and transient (state-dependent changes) types, and differentiating between these two types may aid the treatment process. Nevertheless, in the contemporary literature review of epilepsy, the misleading term "state-dependent" (seizure-related) cognitive impairment has been less appreciated (Besag, 2002).
Pentylenetetrazol (PTZ), a chemoconvulsant routinely used for inducing experimental seizure, causes learning impairment in the Inhibitory Avoidance (IA) response (Kim, Lee, Lee, Jung, \& Lee, 2009; Lee et al., 2010), spatial learning, and emotional reactivity (Becker, Grecksch, \& Brosz, 1995; Mortazavi, Ericson, Story, Hulce, \& Dunbar, 2005; Müller, Bankstahl, Gröticke, \& Löscher, 2009) tests. PTZ is considered as a valuable chemical tool to prepare the experimental models for studying the cognitive problems in epilepsy (Lazarova, Petkova, \& Petkov, 1995). PTZ acts via the Gamma-Aminobutyric Acid (GABA) receptors (Soares et al., 2018).

The interaction between GABA and opioids in learning and memory processes has been approved. For example, the role of dorsal hippocampal GABA-ergic receptors in the modulation of IA memory consolidation is well known (Nasehi, Gerami-Majd, Khakpai, \& Zarrindast, 2018). Modulation of GABA release during morphine withdrawal is reported in the midbrain neurons during slice preparations (Hack, Vaughan, \& Christie, 2003). 
Hippocampal GABAa receptors are involved in the acquisition and expression of morphine-induced conditioning (Rezayof, Razavi, Haeri-Rohani, Rassouli, \& Zarrindast, 2007). Moreover, the involvement of dorsal hippocampal GABA-ergic receptors in the inhibition of morphine-induced amnesia in morphine-sensitized mice (Zarrindast, Hoghooghi, \& Rezayof, 2008) has been indicated. Inhibition of microglia in the basolateral amygdala via GABAa receptors enhanced the morphineinduced antinociception (Kosarmadar, Ghasemzadeh, \& Rezayof, 2015). Expression of the spinal cord GABA transporter in morphine-tolerant male Wistar rat (Siroosi, Manaheji, Dargahi, \& Daniali, 2015) has been demonstrated. Furthermore, recently, the GABA and opioid interaction in the lateral parabrachial nucleus to induce sodium intake (De Oliveira, Andrade, De Luca Jr, Colombari, \& Menani, 2018) was reported.

The brief seizures have different effects on learning and memory in various models (Mao et al., 2009). Although the brief seizure is a short-term phenomenon, its cognitive outcomes continue beyond the apparent seizure behaviors (Jutkiewicz, Baladi, Folk, Rice, \& Woods, 2006; Mao et al., 2009) and may even impair the function of hippocampal place cells (Zhou, Lenck-Santini, \& Holmes, 2007; Zhou, Shatskikh, Liu, \& Holmes, 2007). Reportedly, a single episode of experimental seizure induced by PTZ is followed by a cognitive decline (Aniol et al., 2015).

Moreover, it is well known that PTZ-induced brief seizures alter certain molecules affecting memory, such as $\mathrm{Ca}^{2+} /$ Calmodulin-dependent protein Kinase II (CaMKII) (Dong \& Rosenberg, 2004) and cyclic Adenosine Monophosphate (cAMP) (Pi, Lee, Li, \& Rosenberg, 2004).

Although different learning and memory paradigms have been used to study the effect of PTZ on the cognitive problems in order to simulate the clinical outcomes occurring in epilepsy patients, yet further studies are required to investigate the effects of single/brief seizure on memory models; such as State-Dependent (STD) memory.

The STD memory includes a process, in which the memory retrieval is more efficient when the learners are in the state similar to learning when their memory was formed (Ardjmand, Rezayof, \& Zarrindast, 2011). A considerable body of evidence reveals morphine-STD memory in IA models (Ardjmand et al., 2011; Rezayof, Darbandi, \& Zarrindast, 2008) using single-trial paradigms (Ardjmand et al., 2011). Moreover, the role of GABA in MOR-induced STD is reported by some researchers (Rassouli, Rezayof, \& Zarrindast, 2010; Vas kili, Tayebi, Jafari, Zarrindast, \& Djahanguiri, 2006).
Since the effect of PTZ, as a GABAa antagonist (Shimada \& Yamagata, 2018), on morphine-STD memory has not been studied previously, and considering the fact that the hippocampus is the most epileptogenic anatomic structure in the brain (Cendes et al., 1993) involved in learning and memory (Broadbent, Squire, \& Clark, 2004), the present study was conducted to investigate the effects of intraperitoneal (i.p.) injections of the GABAa receptor antagonist (PTZ) on morphine-STD memory in the rat.

\section{Materials \& Methods}

\subsection{Animals}

Male Wistar rats (10-12 weeks old and weighing 200-220 g) were used. All animals were housed in a polycarbonate cage in a well-ventilated room at $24 \pm 2{ }^{\circ} \mathrm{C}$ with a 12-h light/dark cycle. Free access to standard diet and water was provided for all animals. All experiments were performed during the light phase, from 8 (a.m.) to 2 (p.m.). Each group included seven rats. The Animal Ethics Committee of Kashan University of Medical Sciences (Kashan, Iran) approved the study procedures (Ethics Code: IR.KAUMS. REC.1395.72), which were in accordance with the National Institutes of Health (NIH) Guidelines for the Care and Use of Laboratory Animals (NIH Publications No.: 8023, Revised Edition: 1978).

\subsection{Drugs}

Morphine and PTZ were acquired from Temad (Tehran, Iran) and Sigma (England) Co., respectively. All drugs were dissolved with sterile saline and freshly prepared to the required volume and concentration daily. The pre-/posttrain or pre-test i.p. injections of the drugs were administered after a 30-min interval with respect to the training or testing session.

\subsection{Study design}

\subsubsection{Experiment 1}

This experiment examined the effects of posttraining i.p. administration of different doses of morphine on IA memory retention. Four groups of the animals were used. The control group received posttraining and pre-test injections of saline $(1 \mathrm{ml} / \mathrm{kg})$, whereas the other three groups received posttraining injections of morphine $(2.5,5$, and $7.5 \mathrm{mg} / \mathrm{kg}$ ). On the testing day, all the groups received pre-test saline $(1 \mathrm{ml} / \mathrm{kg})$ treatment $30 \mathrm{~min}$ before testing. 


\subsubsection{Experiment 2}

This experiment evaluated the effects of pre-test i.p. administration of morphine on IA memory retrieval. Five groups of animals were used. On the training day, all groups received posttraining saline $(1 \mathrm{ml} / \mathrm{kg})$ or morphine $(7.5 \mathrm{mg} / \mathrm{kg}) 30 \mathrm{~min}$ after training, whereas on the testing day, four groups received either saline $(1 \mathrm{ml} / \mathrm{kg})$ or morphine $(2.5,5$, and $7.5 \mathrm{mg} / \mathrm{kg}) 30 \mathrm{~min}$ prior to the test.

\subsubsection{Experiment 3}

This experiment examined the interactive effects of PTZ with MOR-induced STD. Four groups of animals were used. The control group received posttraining and pre-test injections of saline $(1 \mathrm{mg} / \mathrm{kg})$. The other three groups received either posttraining/pre-test injections of morphine/morphine (morphine-STD), posttraining/ pre-test injections of saline/PTZ (60 mg/rat), or pretest coadministration of PTZ along with posttraining and pre-test injections of morphine (morphine-induced $\mathrm{STD} \pm \mathrm{PTZ}$ ) 45 and $30 \mathrm{~min}$ before testing, respectively.

\subsection{IA Behavioral testing}

The IA setup comprised two equal-sized compartments $\left(20 \times 20 \times 30 \mathrm{~cm}^{3}\right)$ separated by a wall with a guillotine door located in the middle that could be manually elevated (BorjSanat, Tehran, Iran). The walls and floor of one of the compartments were made of white opaque Plexiglas and were lit with a $25 \mathrm{~W}$ electric bulb placed approximately $50 \mathrm{~cm}$ above the floor of the apparatus. The walls of the other compartment were dark, but the floor of the compartment consisted of parallel stainless steel grids ( $3 \mathrm{~mm}$ in diameter), located at $1-\mathrm{cm}$ intervals. Intermittent electric shocks (frequency $50 \mathrm{~Hz}$, duration $3 \mathrm{~s}$, intensity $1 \mathrm{~mA}$ ) were delivered to the grid floor of the dark compartment using an isolated stimulator (BorjSanat Co, Tehran, Iran).

\subsection{Real-Time PCR experiments}

Total hippocampal RNA was isolated using the RNeasy Kit (Sina Clon, Iran) for each tissue sample, according to the manufacturer's protocol. Quantity and quality of the total RNA were determined via the OD260/280 method using a NanoDrop ND 3300 spectrophotometer (NanoDrop Technologies, USA).

First-strand cDNA synthesis using $1.0 \mu \mathrm{g}$ of total extracted RNA with Oligo (dT) primers was performed with the Prim Script TM RT reagent kit (TAKARA, Japan), according to the manufacturer's instruction.
Quantitative real-time PCR (qRT-PCR) was performed using SYBR Premix Ex Taq TM II (TAKARA, Japan) with specific primers for CREB gene (F: 5'- GAGTGGAGATGCTGCTGTAAC-3', R: 5'-TGTGGAGACTGAATAACTGAT-3') and HPRT (F: 5'-GCTCGAGATGTCATCAAGGAG-3', R: 5'-TGTGGAGACTGAATAACTGAT-3') as an internal reference gene. Cycles for all qRT-PCR were $40 \times 95^{\circ} \mathrm{C}$ for $10 \mathrm{~s}$, $95^{\circ} \mathrm{C}$ for $5 \mathrm{~s}$, and $60^{\circ} \mathrm{C}$ for $34 \mathrm{~s}$. The expression data were calculated by the Pfaffl method (Pfaffl, 2001).

\subsection{Locomotion testing}

All rats were exposed for $5 \mathrm{~min}$ to an open-field during the training (habituation) and after memory tests. The open-field apparatus (Technique Azma, Tabriz, Iran) was made using dark Plexiglas with the dimensions of $60 \times 60 \times 30 \mathrm{~cm}$. The floor of the apparatus was divided into 12 equal zones. Each rat spent $5 \mathrm{~min}$ in the openfield apparatus and the total distance traveled $(\mathrm{cm})$ in zones, as a criterion for spontaneous locomotion, was automatically recorded by the software.

\subsection{Analysis method}

After assessing the normality of data by the Kolmogorov-Smirnov test, the animal behavior was statistically analyzed using the parametric/nonparametric Analysis of Variance (ANOVA), depending on the experimental protocol. The PCR data were analyzed using the Pfaffl method (Pfaffl, 2001) and HPRT as a reference gene. A $\mathrm{P}<0.05$ was considered as statistically significant.

\section{Results}

3.1. Effect of morphine on memory formation, relative hippocampal CREB mRNA expression, and locomotion

Figure 1A depicts the effect of posttraining i.p. administration of morphine on memory retention in the IA learning test. One-way ANOVA and post hoc Holm-Sidak analysis revealed that posttraining administration of different doses of morphine $(2.5,5$, and $7.5 \mathrm{mg} / \mathrm{kg}$, i.p.) impaired memory retention $\left[\mathrm{F}_{3,24}=87.24, \mathrm{P}<0.001\right]$.

In addition, as displayed in Figure 1B, the relative hippocampal CREB mRNA expression was measured in morphine-induced amnesia using RT-PCR. One-way ANOVA and post hoc Holm-Sidak analysis revealed that the CREB mRNA expression in the hippocampus increased in the rats presenting successful memory retention (saline/saline group) compared with the untrained rat 

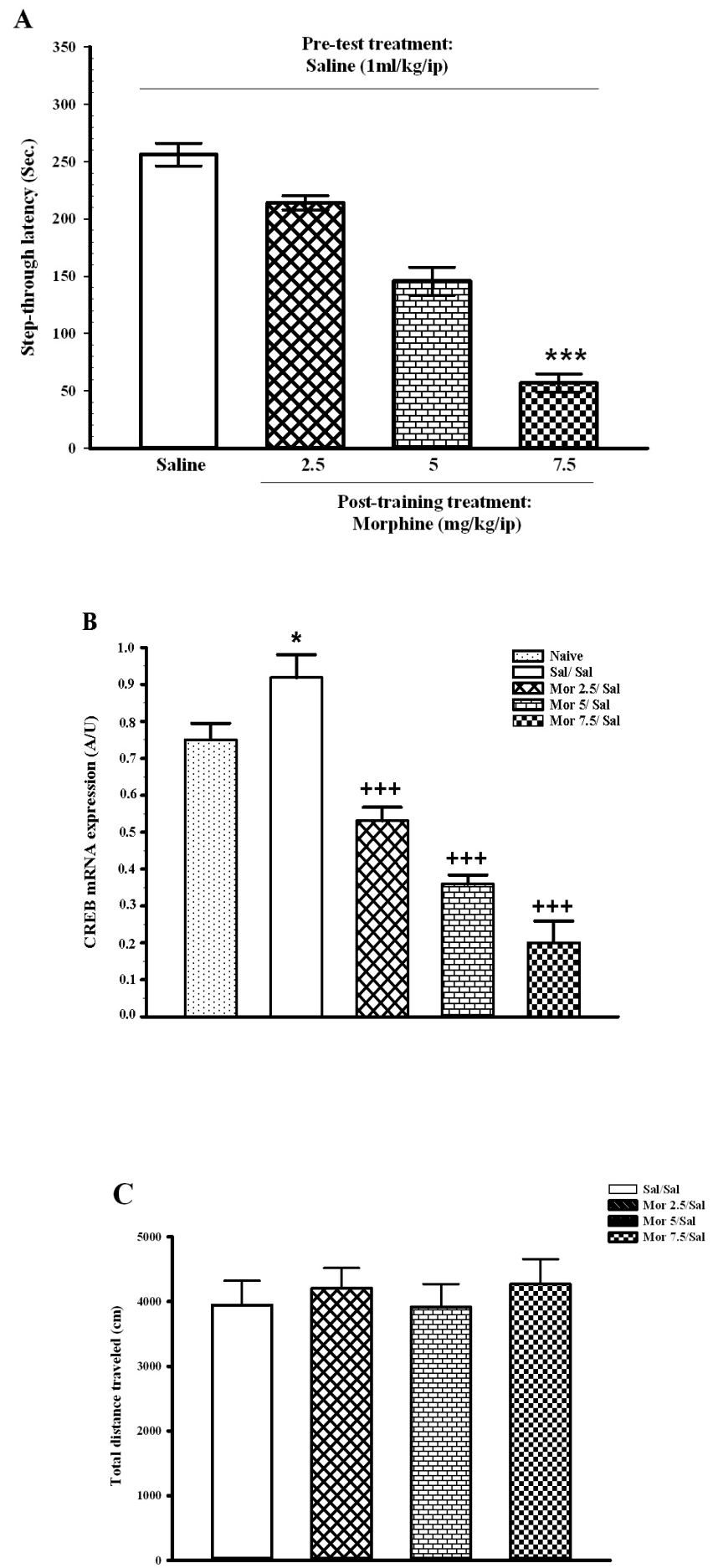

NEUR:SCIENCE

Figure 1. The morphine effect on memory, cyclic adenosine monophosphate response element element-binding (CREB) mRNA expression, and locomotor activity.

A: The effects of posttraining and pre-test saline on the step-through latencies. Each value represents the Mean \pm SEM for 7 rats. *** $\mathrm{P}<0.001$ compared with the posttraining and pre-testing saline; B: The relative expression of CREB mRNA (A/U). Each bar shows the Mean \pm SEM for 4 rats. ${ }^{*} \mathrm{P}<0.05$ compared with the naïve group. ${ }^{+++} \mathrm{P}<0.001$ compared with the saline/ saline group; $\mathrm{C}$ : The locomotor activity as the total distance traveled $(\mathrm{cm})$; The values are represented as the Mean \pm SEM for 7 rats. 

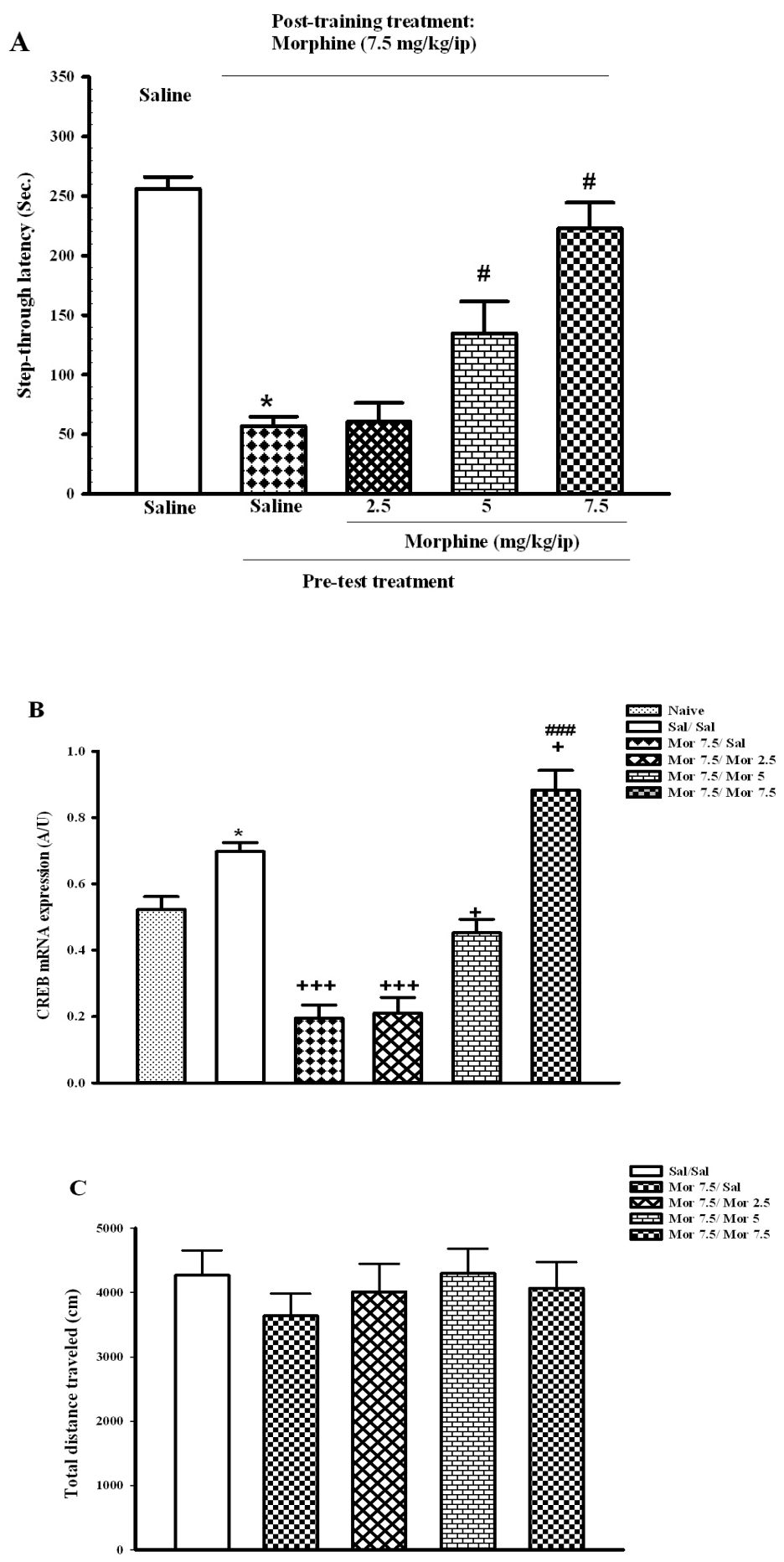

NEUR:SCIENCE

Figure 2. The morphine state-dependent memory, cyclic adenosine monophosphate response element element-binding (CREB) mRNA expression, and locomotor activity.

A: The effect of morphine on state-dependent memory retrieval. Data are shown as Mean \pm SEM for seven animals per group. ${ }^{*} \mathrm{P}<0.05$ compared with the posttraining saline/pre-test saline group; ${ }^{*} \mathrm{P}<0.05$ compared with the posttraining morphine $(7.5 \mathrm{mg} / \mathrm{kg}) /$ pre-test saline group; B: The relative expression of CREB mRNA (A/U). Each bar shows the Mean $\pm S E M$ for 4 rats. ${ }^{*} \mathrm{P}<0.05$ compared with the naïve group; ${ }^{+} \mathrm{P}<0.05$ and ${ }^{+++} \mathrm{P}<0.001$ compared with the saline/ saline group, and ${ }^{\# \# \# P<0.001}$ compared with the morphine/saline group; $\mathrm{C}$ : The locomotor activity as the total distance traveled (cm); The values are represented as the Mean \pm SEM for 7 rats. 


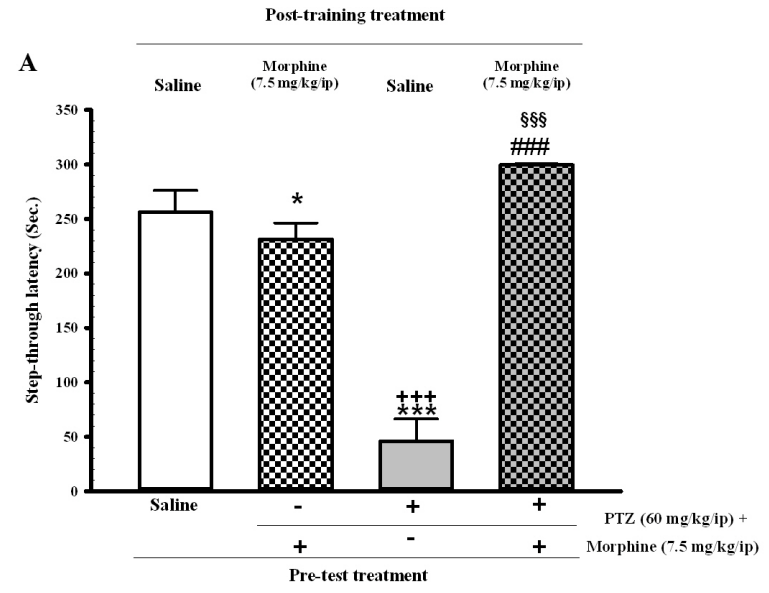

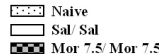 Sal PTZ}

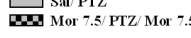
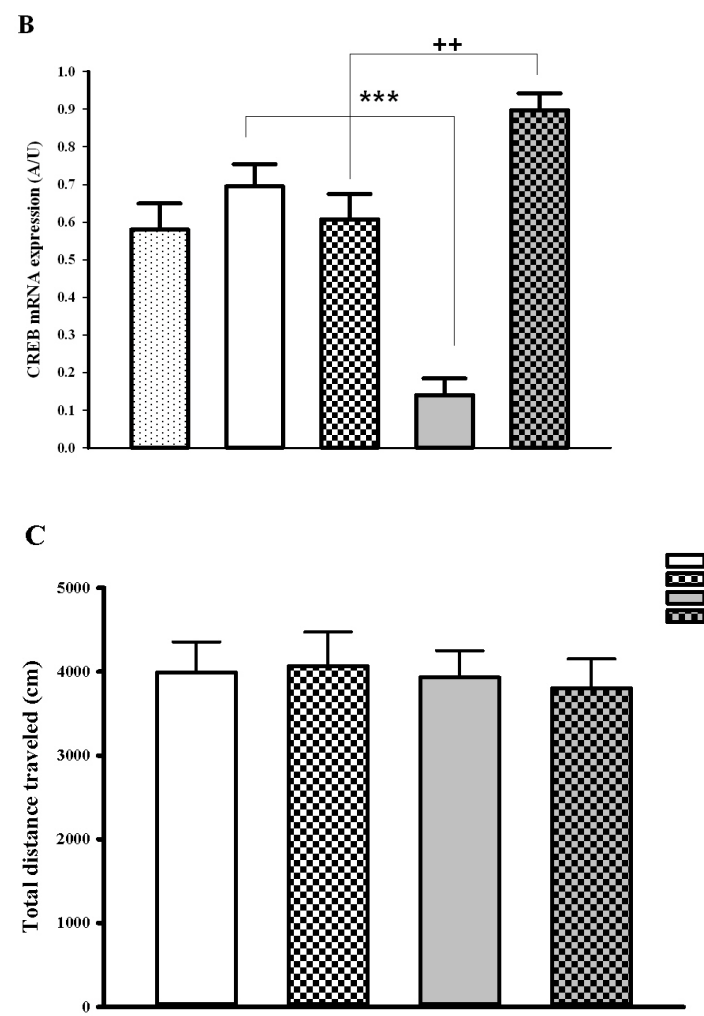

NEUR:SCIENCE

Figure 3. The interaction between morphine state-dependent memory and pentylenetetrazole (PTZ), cyclic adenosine monophosphate response element element-binding (CREB) mRNA expression, and locomotor activity

A: The effects of pre-test PTZ in the presence or absence of morphine. Data are shown as Mean \pm SEM for seven animals per group, ${ }^{*} \mathrm{P}<0.05$ and ${ }^{* * *} \mathrm{P}<0.01$ compared with the posttraining saline/pre-test saline group, ${ }^{+++} \mathrm{P}<0.001,{ }^{\$ \$ \$} \mathrm{P}<0.001$ compared with the post-training morphine/pre-test morphine group and \#\# $\mathrm{P}<0.001$ compared with the posttraining saline/pre-test PTZ group; B: The relative expression of CREB mRNA (A/U). Each bar shows the Mean \pm SEM for 4 rats, ***P<0.001 compared with the saline/saline group, ${ }^{++} \mathrm{P}<0.01$ compared with the morphine/morphine group; $\mathrm{C}$ : The locomotor activity as the total distance traveled $(\mathrm{cm})$. The values are represented as the Mean \pm SEM for 7 rats. 
(naive group) $\left[\mathrm{F}_{4,15}=37.20, \mathrm{P}<0.05\right]$. In contrast, posttraining administration of different doses of morphine $(2.5,5$, and $7.5 \mathrm{mg} / \mathrm{kg}$, i.p.) dose-dependently decreased the hippocampal CREB mRNA expression $(\mathrm{P}<0.001)$ compared with the saline/saline group.

Moreover, Kruskal-Wallis one-way ANOVA of openfield data (presented in Figure 1C) revealed that posttraining morphine administration did not alter the total distance traveled $(\mathrm{cm})$ in an open-field session immediately posttesting, suggesting that the animals did not present voluntary motor disabilities $\left[\mathrm{H}_{3}=1.08 ; \mathrm{P}=0.78\right]$.

3.2. Effect of pre-test administration of Morphine on memory impairment induced by posttraining Morphine (Morphine-induced STD), relative hippocampal CREB mRNA expression and locomotion

Figure 2A depicts the effect of posttraining and pre-test i.p. administration of morphine on memory retrieval in the IA learning test. The Kruskal-Wallis one-way ANOVA revealed that pre-test administration of the effective dose of morphine (7.5 mg/kg, i.p.) significantly reversed the memory impairment, indicating morphine-induced STD memory $\left[\mathrm{H}_{4}=25.77 ; \mathrm{P}<0.001\right]$. Moreover, the post hoc Tukey test indicated a significant difference between the posttraining morphine/pre-test morphine group compared with the posttraining morphine/pre-test saline group $(\mathrm{P}<0.05)$.

In addition, the hippocampal CREB mRNA expression (Figure 2B) was measured in the morphine-induced STD learning via RT-PCR. The one-way ANOVA results revealed that CREB mRNA expression in the hippocampus increased in the rats presenting successful memory retrieval (control group) compared with the untrained rats (naive group) $\left[\mathrm{F}_{5,18}=38.58 ; \mathrm{P}<0.001\right]$. In contrast, posttraining administration of morphine $(7.5 \mathrm{mg} / \mathrm{kg}$, i.p. $)$ decreased the hippocampal CREB mRNA expression $(\mathrm{P}<0.001)$ than that of the control group. Moreover, the Holm-Sidak post hoc analysis revealed that hippocampal CREB mRNA expression in the hippocampus increased $(\mathrm{P}<0.001)$ in morphineinduced STD memory (morphine/morphine group) compared with the morphine-induced amnesia (morphine/saline group; $\mathrm{P}<0.001$ ).

Furthermore, the results of one-way ANOVA of the open-field data (Figure 2C) indicated that morphine-STD learning did not alter the total distance traveled $(\mathrm{cm})$ in an open-field session immediately posttesting, suggesting that the animals did not present voluntary motor disabilities $\left[\mathrm{F}_{4}\right.$, $\left.{ }_{30}=0.45 ; \mathrm{P}=0.78\right]$.
Figure 3A depicts the effect of i.p. pre-test PTZ/posttraining saline, morphine/morphine (morphine-induced STD), and/or coadministration of PTZ and morphine STD on memory retrieval. One-way ANOVA revealed that pre-test administration of PTZ alone (60 mg/kg, i.p.) decreased the step-through latency and induced amnesia $\left[\mathrm{F}_{3,24}=192.78\right.$; $\mathrm{P}<0.001]$; however, the post hoc Holm-Sidak analysis revealed that coadministration of PTZ and morphine STD increased the morphine-STD memory compared with MOR STD (morphine/morphine group; $\mathrm{P}<0.001$ ).

Moreover, the rats in these groups were used to evaluate the hippocampal CREB mRNA expression by RT-PCR (Figure 3B). The one-way ANOVA revealed a significant difference between the groups. Moreover, the results of the post hoc Holm-Sidak test indicated that CREB mRNA expression nonsignificantly increased in the animals that presented successful memory retrieval (control group) than the intact group. In contrast, the pre-test administration of PTZ (60 mg/kg, i.p.) led to decreased hippocampal CREB mRNA expression compared with the control group $(\mathrm{P}<0.001)$. In addition, the hippocampal CREB mRNA expression increased in animals receiving coadministration of PTZ and morphine/morphine (morphine STD) in comparison with MOR-induced STD $(\mathrm{P}<0.01)$.

Furthermore, one-way ANOVA of the open-field data (Figure 3c) revealed that the interaction between morphineSTD memory and PTZ did not alter the total distance traveled $(\mathrm{cm})$ in an open-field session immediately posttesting, suggesting that the animals did not present voluntary motor disabilities $\left[\mathrm{F}_{3,24}=0.97 ; \mathrm{P}=0.96\right]$.

\section{Discussion}

This study presented the interactive effects of PTZ and morphine in an STD memory retrieval paradigm and the consequent changes in the hippocampal CREB mRNA expression.

The findings of the first part of our experiments revealed that posttraining i.p. administration of morphine impaired memory retrieval in the IA paradigm and induced an animal amnesic model. Reportedly, this amnesic effect of posttraining morphine administration has been broadly studied in different memory models (Ardjmand et al., 2011; Castellano, 1975; Ma, Chen, He, Zeng, \& Wang, 2007; Rassouli et al., 2010; Rezayof, Khajehpour, \& Zarrindast, 2009; Zarrindast et al., 2006; Zarrindast, Farajzadeh, Rostami, Rezayof, \& Nourjah, 2005; Zarrindast, Jafari-Sabet, Rezayat, Djahanguiri, \& Rezayof, 2006; Zarrindast, Ardjmand, Rezayof, \& Ahmadi, 2013). 
In addition, the findings of the second part of our experiments revealed that pre-test i.p. administration of morphine also recovered memory impairment and induced morphine-STD memory retrieval. This finding is in accordance with studies reporting that pre-test morphine can recover the impairment induced by posttraining morphine (Farahmandfar, Naghdi, Karimian, Kadivar, \& Zarrindast, 2012; Izquierdo, 1979; Mariani et al., 2011; Rassouli et al., 2010; Zarrindast, Piri, Nasehi, \& Ebrahimi-Ghiri, 2012). According to Koob et al. (Koob, Le Moal, \& Thompson, 2010), as the pre-test application of a drug has effects on memory retrieval, changes in the animal behavior can be attributed to the drug's effects on sensory/motor function; however, in our study, the effect of drugs on animal motor function measured by the open-field test was ruled out.

Moreover, using RT-PCR for measuring the relative mRNA expression, we noticed that hippocampal CREB mRNA expression dose-dependently decreased in morphine-induced amnesia, whereas it significantly increased in morphine-STD memory. Reportedly, changes in CREB expression in different brain regions were observed following morphine administration (Ren et al., 2013). For example, while memory formation in a single-trial IA learning model increased the hippocampal CREB (Cammarota et al., 2000), the administration of opioids in several brain regions decreased the CREB (Beitner, Duman, \& Nestler, 1989; Espinosa et al., 2008). In accordance with our findings, a study by Bekinschtein et al. (Bekinschtein et al., 2007) on a fear model revealed the main role of protein synthesis $12 \mathrm{~h}$ after training for the strength of long-term memory. Moreover, Rossato et al. (Rossato, Bevilaqua, Izquierdo, Medina, \& Cammarota, 2009) has reported that the endurance of IA memory depends on the activity and elevation of CREB, $12 \mathrm{~h}$ after the acquisition. According to another study by Bekinschtein et al. (Bekinschtein et al., 2010), the endurance of long-term memory depends on protein synthesis about $12 \mathrm{~h}$ post-acquisition. Furthermore, in a study by Morón et al. (Morón et al., 2010), the changes in the extent of phosphorylation of various signaling molecules, besides CREB, were reported following morphine administration. In this study, the single injection of morphine led to considerable decreases in CREB phosphorylation in all brain areas, and a correlation was found between the expression of conditioned response to morphine and an increase in phosphorylated CREB levels in certain brain areas (e.g. the hippocampus).

The findings obtained from the third part of our experiment revealed that while the pre-test PTZ alone impaired the IA, the coadministration of pre-test PTZ with post- training morphine/pre-test morphine (morphine-STD) increased the morphine-STD memory. As reported by few researchers, the amnesic effects of posttraining PTZ have been studied in different memory models in rodents (Baratti, De Erausquin, \& Faiman, 1990; Bookin \& Pfeifer, 1977; Drago et al., 1990; Homayoun, Khavandgar, \& Zarrindast, 2001; Lazarova et al., 1995). In the present study, we used a single dose of PTZ $(60 \mathrm{mg} / \mathrm{kg})$ to induce a brief seizure model, as experienced by Mao et al. (Mao et al., 2009). Our findings are also in accordance with the previous studies revealing that similar doses of the PTZ can impair memory (Palfai \& Kurtz, 1976; Viu, Zapata, Capdevila, Skolnick, \& Trullas, 2000).

Collectively, cognitive impairment was reported in different seizure models in animals (Majak \& Pitkänen, 2004). In addition, it was reported that memory impairments are also seen in children with idiopathic absence epilepsy and with no clear cerebral pathology (Gascoigne et al., 2012).

Animal seizure models are considered as favorite experimental tools to study the cognitive impairment following a single seizure event; however, the outcome of such studies is clinically important. Pathophysiologically, the cognitive impairment following seizures is due to excitotoxic injury. Nevertheless, cognitive impairments with no apparent neuronal injury were observed (Aniol et al., 2013). In this regard, Assaf et al. (Assaf, Fishbein, Gafni, Keren, \& Sarne, 2011) have reported a mild cognitive impairment in adult mice, 3-5 weeks after a single application of PTZ, and other researchers reported no obvious cerebral pathology (Kadar, Cohen, Sahar, Alkalai, \& Shapira, 1992; Kasof et al., 1995; Pane egyres, 1998; Planas, Soriano, Ferrer, \& Farré, 1994). The aforementioned data supports the notion that even a brief seizure has the potential to impair certain memory functions (Kemppainen, Nissinen, \& Pitkänen, 2006; Mao et al., 2009; McKay \& Persinger, 2004).

Furthermore, our findings revealed that whereas pre-test administration of PTZ decreased the hippocampal CREB mRNA expression in PTZ-induced amnesia, it significantly increased the hippocampal CREB mRNA expression in PTZ/morphine-STD coadministration group.

Alterations in cAMP (Pi et al., 2004) and CaMKII, as the main memory markers, were reported following single seizure models by PTZ (Dong \& Rosenberg, 2004). In accordance with our present findings, the decreased expression of brain CREB gene has been previously reported in PTZ-induced seizure models (Pi et al., 2004; Wang, Wang, Wang, \& Fan, 2008), which was reversed by an opioid antagonist, naltrexone (Baratti et 
al., 1990). The finding that posttraining injection of naltrexone reversed the PTZ-induced memory impairment, establishes the role of opioids in memory (Baratti, 1987). A similar role of $\mu$-opioid receptors was observed with morphine STD because the amnesia induced by pre-test morphine could be reversed by naloxone (Zarrindast \& Rezayof, 2004). This dual role of $\mu$-opioid receptors in the aforementioned events reveals an extra-augmented STD effect, as seen in our study.

Apart from the aforementioned results, even the seizures in the absence of clinical convulsions with the only electrophysiologically detected wave alteration (Jutkiewicz et al., 2006), might result in memory impairment. It is argued that among the other reasons, the place cell disorders following a brief seizure event may be the reason for spatial memory impairment (Zhou et al., 2007; Zhou et al., 2007). Accordingly, such brief events mimicked by PTZ and via antagonizing the effect of GABA can cause learning impairment (Moser, Krobert, Moser, \& Morris, 1998; Zhou, et al., 2007). Thus, it was reported that opioids have modulatory effects on GABA neurons (Schroeder \& Schneider, 2002). Thus, opioids have the potential of recovering the impaired memory induced by opioids (Halonen, Pitkänen, Partanen, Hyttinen, \& Riekkinen, 1992; Jafari, Zarrindast, \& Djahanguiri, 2006; Ruzicka \& Jhamandas, 1991) or other drugs (Zarrindast et al., 2006). Considering the notion that opioids are released following PTZ administration (Rocha et al., 1999) and the recovery potential of the impaired memory by opioids in the morphine-STD group, the observed exaggerated memory recovery in our study may presumably be due to the additional effect of released opioids. This dual role of $\mu$-opioid receptors in both aforementioned events can be considered as additional proof in our study.

Moreover, the role of the GABA receptors on IA learning and memory (Nakagawa, Iwasaki, Ishima, \& Kimura, 1993; Nakagawa, Sasaki, \& Takashima, 1999; Reis et al., 2009) and the involvement of GABAa receptors in morphine-STD memory was previously reported (Rassouli et al., 2010).

Another possible explanation is that the GABA neurotransmitter is also involved in reward-related behaviors (Zhu \& Pan, 2004). Based on the reward theory and the potential of few drugs in stimulating the brain's reward system as well as the notion that the hippocampus is the main area involved in reward-related learning (Rezayof, Zarrindast, Sahraei, \& Haeri-Rohani, 2003), biologically, the morphine-STD memory can be considered as a reward-induced learning and the morphineSTD memory may be linked to the morphine reward
(Zarrindast \& Rezayof, 2004). From this point of view, the involvement of amygdala GABAa receptors in morphine reward (Zarrindast \& Rezayof, 2004) is reported and a majority of reports on the effect of central injection of the GABAa agonist support this claim (Laviolette \& Van Der Kooy, 2001; Xi \& Stein, 1998). Reportedly, morphine directly plays a crucial role in rewarding response via the activation of the mesolimbic reward system (Olmstead \& Franklin, 1997). In contrast, the opiate's role via an indirect mechanism on GABA-ergic neurons of the reward circuit is important (Xi \& Stein, 2000, 2002). Through this indirect mechanism, opiates can activate the reward system by inhibiting the GABAergic interneurons for decreasing dopamine, and consequently disinhibiting dopamine neurons (Kelle, Stinus, \& Iversen, 1980; Xi \& Stein, 1998, 2002). Moreover, the findings that the role of GABA in opioid reward is mediated specifically via GABAa receptors (Laviolette \& Van Der Kooy, 2001) and that basolateral amygdala GABA receptors are involved in reward-related learning (Zarrindast et al., 2004), establishes a cross-talk between the GABA and the opioid systems via $\mu$-opioid receptors (Zhu \& Pan, 2004). Accordingly, the possible involvement of the GABAa receptor in the potentiation of the pre-test morphine response can be hypothesized. In this regard, Rassouli et al. (Rassouli et al., 2010) reported that blocking of GABAa receptors of the central amygdala enhanced the effect of low-dose morphine in an STD model.

Moreover, considering the fact that opioids induce their excitatory role via inhibition of GABA release (Depaulis, Morgan, \& Liebeskind, 1987; Leite-Panissi \& Menescal-de-Oliveira, 2002), our study presented a similar inhibition induced by the application of GABAa antagonist, PTZ. Both direct and indirect experimental evidence supports the interaction between the GABA and opioids. PTZ, which has been proposed as a GABAa receptor antagonist (Shimada \& Yamagata, 2018), inactivates GABA-mediated chloride conductance (Corda et al., 1990, 1991) and increases the extracellular concentration of inhibitory opioid peptides (Rocha et al., 1999). In addition, GABA decreases the release of the opioid in some brain regions (Bourgoin, Cesselin, Artaud, Glowinski, \& Hamon, 1982; Osborne \& Herz, 1980), and the blockade of GABA current by PTZ (Corda, Giorgi, Longoni, Orlandi, \& Biggio, 1990; Corda et al., 1991) blocks the tonic inhibitory tone for opioid release (Rocha et al., 1999).

In addition to the opioid releasing mechanism, the increased level of excitatory amino acids following the intracerebral injection of rats with PTZ has been reported (Halonen et al., 1992; Rocha et al., 1999). Although the 
excitatory amino acids primarily cause an opioid release in some brain regions (Ruzicka \& Jhamandas, 1991), the augmented glutamate released by PTZ leads to a secondary increase in the extracellular opioids (Zubieta et al., 1985).

Besides using for inducing animal seizure models, PTZ, as a GABAa antagonist (Shimada \& Yamagata, 2018), is routinely used for assessing learning and memory impairments following seizure events (Genkova-Papazova \& Lazarova-Bakarova, 1995; Shaw \& Webster, 1979).

Based on the previous reports (Rocha et al., 1999) that reveal the strong activation of the brain opioid system following both the chemical excitation by PTZ or the electrical excitation (Rocha, Ackermann, Chugani, \& Engel Jr, 1994; Rocha, Ackermann, Nassir, Chugani, \& Engel Jr, 1993; Talavera, Oman, Asai, \& Condés-Lara, 1989; Vindrola, Asai, Zubieta, \& Linares, 1983; Vindrola, Briones, Asai, \& Fernández-Guardiola, 1981), it can be assumed that similar to the pre-test morphine effect, the aforementioned excitation via releasing opioids is another alternative path, through which morphine can induce an additional STD-like condition, thereby augmenting the morphine-STD memory (Rocha et al., 1994; Rocha et al., 1993; Talavera et al., 1989; Vindrola et al., 1983; Vindrola et al., 1981).

Notably, our results indicated that cognitive impairment induced by PTZ is not essentially related to PTZinduced seizures. Previous reports have revealed that gangliosides with no anticonvulsive effect in PTZ-treated rats have an improving effect on PTZ-induced learning impairment. Moreover, preventing PTZ-induced seizures by diazepam does not protect against PTZ-induced learning impairment. Therefore, it may be proposed that the suppression of seizures is not sufficient to prevent cognitive impairment in epilepsies (Homayoun et al., 2001).

In conclusion, presumably, the certain interactive effect of PTZ on morphine-STD memory is mediated via the GABA-opioid system and the hippocampal CREB signaling may play a pivotal role in it. Our findings may suggest new therapeutic methods regarding the application of morphine in order to deal with the learning and memory disorders in seizure patients.

\section{Ethical Considerations}

Compliance with ethical guidelines

All experiments were conducted according to the Ethics Committee of Kashan University of Medical
Sciences (Committee registration Code: IR.KAUMS REC.1395.72).

\section{Funding}

This study was part of the MSc. thesis of Marziyeh Tavassoli funded and supported by the Deputy of Research, Kashan University of Medical Sciences, Kashan, Iran. This research was financially supported by a grant (No. 9572) by the Deputy of Research, Kashan University of Medical Sciences, Kashan, Iran.

\section{Authors' contributions}

Conceptualization, methodology, investigation, writing-review \& editing, funding acquisition and supervision, supervision, project administration, analysis statistical, writing original draft, art work: Abolfazl Ardjmand; Data acquisition: Marziyeh Tavassoli.

\section{Conflict of interest}

The authors declared no conflict of interest.

\section{Acknowledgments}

The authors would like to thank the Deputy of Research, Kashan University of Medical Sciences for giving the grant.

\section{Reference}

Aniol, V., Ivanova-Dyatlova, A. Y., Tishkina, A., Fominykh, V., Kvichanskii, A., \& Gulyaeva, N. (2015). A single episode of seizures induced by pentylenetetrazole is followed by a cognitive decline. Opera Medica et Physiologica, 1(1), S1. https:// cyberleninka.ru/article/n/

Aniol, V. A., Ivanova-Dyatlova, A. Y., Keren, O., Guekht, A. B., Sarne, Y., \& Gulyaeva, N. V. (2013). A single pentylenetetrazole-induced clonic-tonic seizure episode is accompanied by a slowly developing cognitive decline in rats. Epilepsy $\mathcal{E}$ Behavior, 26(2), 196-202. [DOI:10.1016/j.yebeh.2012.12.006] [PMID]

Ardjmand, A., Rezayof, A., \& Zarrindast, M. R. (2011). Involvement of central amygdala NMDA receptor mechanism in morphine state-dependent memory retrieval. Neuroscience Research, 69(1), 25-31. [DOI:10.1016/j.neures.2010.09.005] [PMID]

Assaf, F., Fishbein, M., Gafni, M., Keren, O., \& Sarne, Y. (2011). Pre-and post-conditioning treatment with an ultra-low dose of $\Delta$ 9-Tetrahydrocannabinol (THC) protects against Pentylenetetrazole (PTZ)-induced cognitive damage. $\mathrm{Be}$ 
havioural Brain Research, 220(1), 194-201. [DOI:10.1016/j. bbr.2011.02.005] [PMID]

Baratti, C., De Erausquin, G., \& Faiman, C. (1990). Brain opioid peptides may participate in the reversal of pentylenetetrazolinduced amnesia. Methods and Findings in Experimental and Clinical Pharmacology, 12(7), 451-6. [PMID]

Baratti, C. M. (1987). The impairment of retention induced by pentylenetetrazol in mice may be mediated by a release of opioid peptides in the brain. Behavioral and Neural Biology, 48(2), 183-96. [DOI:10.1016/S0163-1047(87)90724-2]

Becker, A., Grecksch, G., \& Brosz, M. (1995). Antiepileptic drugs-their effects on kindled seizures and kindling-induced learning impairments. Pharmacology Biochemistry and Behavior, 52(3), 453-9. [DOI:10.1016/0091-3057(95)00137-L]

Beitner, D. B., Duman, R. S., \& Nestler, E. J. (1989). A novel action of morphine in the rat locus coeruleus: persistent decrease in adenylate cyclase. Molecular Pharmacology, 35(5), 559-64. http://citeseerx.ist.psu.edu/viewdoc/download?do $i=10 \cdot 1 \cdot 1 \cdot 970.8685 \&$ rep $=$ rep $1 \&$ type $=p d f$

Bekinschtein, P., Cammarota, M., Igaz, L. M., Bevilaqua, L. R., Izquierdo, I., \& Medina, J. H. (2007). Persistence of long-term memory storage requires a late protein synthesis-and BDNFdependent phase in the hippocampus. Neuron, 53(2), 261-77. [DOI:10.1016/j.neuron.2006.11.025] [PMID]

Bekinschtein, P., Katche, C., Slipczuk, L., Gonzalez, C., Dorman, G., \& Cammarota, M. (2010). Persistence of long-term memory storage: New insights into its molecular signatures in the hippocampus and related structures. Neurotoxicity Research, 18(3-4), 377-385. [DOI:10.1007/s12640-010-9155-5] [PMID]

Besag, F. M. Subtle cognitive and behavioral effects of epilepsy. Cambridge: Cambridge University Press; 2002. https://books. google.com/books?

Bookin, H. B., \& Pfeifer, W. D. (1977). Effect of lysine vasopressin on pentylenetetrazol-induced retrograde amnesia in rats. Pharmacology Biochemistry and Behavior, 7(1), 51-4. [DOI:10.1016/0091-3057(77)90009-0]

Bourgoin, S., Cesselin, F., Artaud, F., Glowinski, J., \& Hamon, M. (1982). In vivo modulations by GABA-related drugs of Met-enkephalin release in basal ganglia of the cat brain. Brain Research, 248(2), 321-30. [DOI:10.1016/0006-8993(82)90590-X]

Broadbent, N. J., Squire, L. R., \& Clark, R. E. (2004). Spatial memory, recognition memory, and the hippocampus. Proceedings of the National Academy of Sciences, 101(40), 14515-14520. [DOI:10.1073/pnas.0406344101] [PMID] [PMCID]

Cammarota, M., Bevilaqua, L. R., Ardenghi, P., Paratcha, G., de Stein, M. L., \& Izquierdo, I., et al. (2000). Learning-associated activation of nuclear MAPK, CREB and Elk-1, along with Fos production, in the rat hippocampus after a one-trial avoidance learning: Abolition by NMDA receptor blockade. Molecular Brain Research, 76(1), 36-46. [DOI:10.1016/S0169328X(99)00329-0]

Castellano, C. (1975). Effects of morphine and heroin on discrimination learning and consolidation in mice. Psychopharmacology, 42(3), 235-42. [DOI:10.1007/BF00421262] [PMID]

Cendes, F., Andermann, F., Gloor, P., Evans, A., Jones-Gotman, M., \& Watson, C., et al. (1993). MRI volumetric measurement of amygdala and hippocampus in temporal lobe epilepsy Neurology, 43(4), 719. [DOI:10.1212/WNL.43.4.719] [PMID]

Corda, M., Giorgi, O., Longoni, B., Orlandi, M., \& Biggio, G. (1990). Decrease in the function of the $\gamma$-aminobutyric acidcoupled chloride channel produced by the repeated administration of pentylenetetrazol to rats. Journal of Neurochemistry, 55(4), 1216-21. [DOI:10.1111/j.1471-4159.1990.tb03127.x] [PMID]

Corda, M. G., Orlandi, M., Lecca, D., Carboni, G., Frau, V., \& Giorgi, O. (1991). Pentylenetetrazol-induced kindling in rats: effect of GABA function inhibitors. Pharmacology Biochemistry and Behavior, 40(2), 329-33. [DOI:10.1016/0091-3057(91)90562-G]

De Oliveira, L. B., Andrade, C. A., De Luca Jr, L. A., Colombari, D. S., \& Menani, J. V. (2018). Opioid and $\alpha^{2}$ adrenergic mechanisms are activated by GABA agonists in the lateral parabrachial nucleus to induce sodium intake. Brain Research Bulletin 139, 174-81. [DOI:10.1016/j.brainresbull.2018.02.008] [PMID]

Depaulis, A., Morgan, M. M., \& Liebeskind, J. C. (1987). GABAergic modulation of the analgesic effects of morphine microinjected in the ventral periaqueductal gray matter of the rat. Brain Research, 436(2), 223-8. [DOI:10.1016/00068993(87)91665-9]

Dong, Y., \& Rosenberg, H. C. (2004). Brief seizure activity alters $\mathrm{Ca}^{2+} /$ calmodulin dependent protein kinase II dephosphorylation and subcellular distribution in rat brain for several hours. Neuroscience Letters, 357(2), 95-8. [DOI:10.1016/j.neut let.2003.11.069] [PMID]

Drago, F., Grassi, M., Valerio, C., Spadaro, F., D’Agata, V., \& Lauria, N. (1990). Effects of vinburnine on experimental models of learning and memory impairments. Pharmacology Biochemistry and Behavior, 37(1), 53-7. [DOI:10.1016/00913057(90)90040-O]

Espinosa, V. P., Liu, Y., Ferrini, M., Anghel, A., Nie, Y., \& Tripathi, P. V. (2008). Differential regulation of prohormone convertase $1 / 3$, prohormone convertase 2 and phosphorylated cyclic-AMP-response element binding protein by short-term and long-term morphine treatment: implications for understanding the "switch" to opiate addiction. Neuroscience, 156(3), 788-99. [DOI:10.1016/j.neuroscience.2008.07.063] [PMID] [PMCID]

Farahmandfar, M., Naghdi, N., Karimian, S. M., Kadivar, M., \& Zarrindast, M. R. (2012). Amnesia induced by morphine in spatial memory retrieval inhibited in morphine-sensitized rats. European Journal of Pharmacology, 683(1-3), 132-9. [DOI:10.1016/j.ejphar.2012.02.038] [PMID]

Gascoigne, M. B., Barton, B., Webster, R., Gill, D., Antony, J., \& Lah, S. S. (2012). Accelerated long-term forgetting in children with idiopathic generalized epilepsy. Epilepsia, 53(12), 213540. [DOI:10.1111/j.1528-1167.2012.03719.x] [PMID]

Genkova-Papazova, M. G., \& Lazarova-Bakarova, M. B (1995). Pentylenetetrazole kindling impairs long-term memory in rats. European Neuropsychopharmacology, 5(1), 53-6. [DOI:10.1016/0924-977X(94)00134-W]

Hack, S. P., Vaughan, C. W., \& Christie, M. J. (2003). Modulation of GABA release during morphine withdrawal in midbrain neurons in vitro. Neuropharmacology, 45(5), 575-84. [DOI:10.1016/S0028-3908(03)00205-3]

Halonen, T., Pitkänen, A., Partanen, J., Hyttinen, J.-M., \& Riekkinen, P. (1992). Amino acid levels in cerebrospinal fluid of 
rats after administration of pentylenetetrazol. Comparative Biochemistry and Physiology Part C: Comparative Pharmacology, 101(1), 21-5. [DOI:10.1016/0742-8413(92)90194-C]

Herfurth, K., Kasper, B., Schwarz, M., Stefan, H., \& Pauli, E. (2010). Autobiographical memory in temporal lobe epilepsy: role of hippocampal and temporal lateral structures. Epilepsy \& Behavior, 19(3), 365-71. [DOI:10.1016/j.yebeh.2010.07.012] [PMID]

Homayoun, H., Khavandgar, S., \& Zarrindast, M. R. (2001). Effects of adenosine receptor agonists and antagonists on pentylenetetrazole-induced amnesia. European Journal of Pharmacology, 430(2-3), 289-94. [DOI:10.1016/S0014-2999(01)01376-0]

Izquierdo, I. (1979). Effect of naloxone and morphine on various forms of memory in the rat: Possible role of endogenous opiate mechanisms in memory consolidation. Psychopharmacology, 66(2), 199-203. [DOI:10.1007/BF00427631] [PMID]

Jutkiewicz, E. M., Baladi, M. G., Folk, J. E., Rice, K. C., \& Woods, J. H. (2006). The convulsive and electroencephalographic changes produced by nonpeptidic $\delta$-opioid agonists in rats: Comparison with pentylenetetrazol. Journal of Pharmacology and Experimental Therapeutics, 317(3), 1337-48. [DOI:10.1124/ jpet.105.095810] [PMID]

Kadar, T., Cohen, G., Sahar, R., Alkalai, D., \& Shapira, S. (1992). Long-term study of brain lesions following soman, in comparison to DFP and metrazol poisoning. Human \& Experimental Toxicology, 11(6), 517-23. [DOI:10.1177/0960327192011006 13] [PMID]

Kasof, G., Mandelzys, A., Maika, S., Hammer, R., Curran, T., \& Morgan, J. (1995). Kainic acid-induced neuronal death is associated with DNA damage and a unique immediate-early gene response in c-fos-lacZ transgenic rats. Journal of Neuroscience, 15(6), 4238-49. [DOI:10.1523/JNEUROSCI.15-06-04238.1995] [PMID] [PMCID]

Kelle, A. E., Stinus, L., \& Iversen, S. D. (1980). Interactions between D-ala-met-enkephalin, A10 dopaminergic neurones, and spontaneous behaviour in the rat. Behavioural Brain Research, 1(1), 3-24. [DOI:10.1016/0166-4328(80)90043-1]

Kemppainen, E. S., Nissinen, J., \& Pitkänen, A. (2006). Fear conditioning is impaired in systemic kainic acid and amygdala-stimulation models of epilepsy. Epilepsia, 47(5), 820-9. [DOI:10.1111/j.1528-1167.2006.00542.x] [PMID]

Kim, Y. H., Lee, Y., Lee, H., Jung, M. W., \& Lee, C. J. (2009). Impaired avoidance learning and increased hsp70 mRNA expression in pentylenetetrazol-treated zebrafish. Animal Cells and Systems, 13(3), 275-81. [DOI:10.1080/19768354.2009.9647 219]

Koob, G. F., Le Moal, M., \& Thompson, R. F. Encyclopedia of behavioral neuroscience. Elsevier; 2010.

Kosarmadar, N., Ghasemzadeh, Z., \& Rezayof, A. (2015). Inhibition of microglia in the basolateral amygdala enhanced morphine-induced antinociception: Possible role of GABA A receptors. European Journal of Pharmacology, 765, 157-63. [DOI:10.1016/j.ejphar.2015.08.027] [PMID]

Kwan, P., \& Brodie, M. J. (2001). Neuropsychological effects of epilepsy and antiepileptic drugs. The Lancet, 357(9251), 21622. [DOI:10.1016/S0140-6736(00)03600-X]

Laviolette, S. R., \& Van Der Kooy, D. (2001). GABAA receptors in the ventral tegmental area control bidirectional reward sig- nalling between dopaminergic and non-dopaminergic neural motivational systems. European Journal of Neuroscience, 13(5), 1009-15. [DOI:10.1046/j.1460-9568.2001.01458.x] [PMID]

Lazarova, M., Petkova, B., \& Petkov, V. (1995). Effect of dotarizine on electroconvulsive shock or pentylenetetrazol-induced amnesia and on seizure reactivity in rats. Methods and Findings in Experimental and Clinical Pharmacology, 17(1), 53-8. [PMID]

Lee, Y., Kim, D., Kim, Y.-H., Lee, H., \& Lee, C.-J. (2010). Improvement of pentylenetetrazol-induced learning deficits by valproic acid in the adult zebrafish. European Journal of Pharmacology, 643(2-3), 225-31. [DOI:10.1016/j.ejphar.2010.06.041] [PMID]

Leite-Panissi, C. R. A., \& Menescal-de-Oliveira, L. (2002). Central nucleus of the amygdala and the control of tonic immobility in guinea pigs. Brain Research Bulletin, 58(1), 13-19. [DOI:10.1016/S0361-9230(02)00748-7]

Ma, M., Chen, Y., He, J., Zeng, T., \& Wang, J. (2007). Effects of morphine and its withdrawal on Y-maze spatial recognition memory in mice. Neuroscience, 147(4), 1059-65. [DOI:10.1016/j. neuroscience.2007.05.020] [PMID]

Majak, K., \& Pitkänen, A. (2004). Do seizures cause irreversible cognitive damage? Evidence from animal studies. Epilepsy $\mathcal{E}$ Behavior, 5, 35-44. [DOI:10.1016/j.yebeh.2003.11.012] [PMID]

Mao, R. R., Tian, M., Yang, Y. X., Zhou, Q. X., Xu, L., \& Cao, J. (2009). Effects of pentylenetetrazol-induced brief convulsive seizures on spatial memory and fear memory. Epilepsy $\mathcal{E} B e$ havior, 15(4), 441-4. [DOI:10.1016/j.yebeh.2009.05.015] [PMID]

Mariani, R. K., Mello, C. F., Rosa, M. M., Ceretta, A. P. C., Camera, K., \& Rubin, M. A. (2011). Effect of naloxone and morphine on arcaine-induced state-dependent memory in rats Psychopharmacology, 215(3), 483-91. [DOI:10.1007/s00213-0112215-6] [PMID]

McKay, B., \& Persinger, M. (2004). Normal spatial and contextual learning for ketamine-treated rats in the pilocarpine epilepsy model. Pharmacology Biochemistry and Behavior, 78(1) 111-9. [DOI:10.1016/j.pbb.2004.02.019] [PMID]

Morón, J. A., Gullapalli, S., Taylor, C., Gupta, A., Gomes, I., \& Devi, L. A. (2010). Modulation of opiate-related signaling molecules in morphine-dependent conditioned behavior: Conditioned place preference to morphine induces CREB phosphorylation. Neuropsychopharmacology, 35(4), 955-66. [DOI:10.1038/npp.2009.199] [PMID] [PMCID]

Mortazavi, F., Ericson, M., Story, D., Hulce, V. D., \& Dunbar, G. L. (2005). Spatial learning deficits and emotional impairments in pentylenetetrazole-kindled rats. Epilepsy $\mathcal{E}$ Behavior, 7(4), 629-38. [DOI:10.1016/j.yebeh.2005.08.019] [PMID]

Moser, E. I., Krobert, K. A., Moser, M.-B., \& Morris, R. G. (1998). Impaired spatial learning after saturation of long-term potentiation. Science, 281(5385), 2038-42. [DOI:10.1126/scii ence.281.5385.2038] [PMID]

Müller, C. J., Bankstahl, M., Gröticke, I., \& Löscher, W. (2009). Pilocarpine vs. lithium-pilocarpine for induction of status epilepticus in mice: development of spontaneous seizures, behavioral alterations and neuronal damage. European Journal of Pharmacology, 619(1-3), 15-24. https://www.sciencedirect. com/science/article/abs/pii/S0014299909006128 
Nakagawa, Y., Iwasaki, T., Ishima, T., \& Kimura, K. (1993). Interaction between benzodiazepine and GABA-A receptors in state-dependent learning. Life sciences, 52(24), 1935-45. [DOI:10.1016/0024-3205(93)90634-F]

Nakagawa, Y., Sasaki, A., \& Takashima, T. (1999). The GABAB receptor antagonist CGP36742 improves learned helplessness in rats. European Journal of Pharmacology, 381(1), 1-7. [DOI:10.1016/S0014-2999(99)00567-1]

Nasehi, M., Gerami-Majd, F., Khakpai, F., \& Zarrindast, M.R. (2018). Dorsal hippocampal cannabinergic and GABAergic systems modulate memory consolidation in passive avoidance task. Brain research Bulletin, 137, 197-203. [DOI:10.1016/j. brainresbull.2017.11.017] [PMID]

Olmstead, M. C., \& Franklin, K. B. (1997). The development of a conditioned place preference to morphine: effects of microinjections into various CNS sites. Behavioral Neuroscience, 111(6), 1324-34. [DOI:10.1037/0735-7044.111.6.1324] [PMID]

Osborne, H., \& Herz, A. (1980). K+-evoked release of met-enkephalin from rat striatum in vitro: effect of putative neurotransmitters and morphine. Naunyn-Schmiedeberg's archives of Pharmacology, 310(3), 203-9. [DOI:10.1007/BF00499911] [PMID]

Palfai, T., \& Kurtz, P. (1976). Dose-related effects of Metrazol on retention and EEG. Pharmacology Biochemistry and Behavior, 4(2), 123-7. [DOI:10.1016/0091-3057(76)90003-4]

Panegyres, P. (1998). The effects of excitotoxicity on the expression of the amyloid precursor protein gene in the brain and its modulation by neuroprotective agents. Journal of Neural Transmission, 105(4-5), 463-478. [DOI:10.1007/s007020050070] [PMID]

Pfaffl, M. W. (2001). A new mathematical model for relative quantification in real-time RT-PCR. Nucleic Acids Research, 29(9), e45. [DOI:10.1093/nar/29.9.e45] [PMID] [PMCID]

Pi, X., Lee, J., Li, F., \& Rosenberg, H. C. (2004). Decreased expression of brain cAMP response element-binding protein gene following pentylenetetrazol seizure. Molecular Brain Research, 127(1-2), 60-7. [DOI:10.1016/j.molbrainres.2004.05.006] [PMID]

Planas, A. M., Soriano, M. A., Ferrer, I., \& Farré, E. R. (1994). Regional expression of inducible heat shock protein-70 mRNA in the rat brain following administration of convulsant drugs. Molecular Brain Research, 27(1), 127-37. [DOI:10.1016/0169328X(94)90193-7]

Rassouli, Y., Rezayof, A., \& Zarrindast, M. R. (2010). Role of the central amygdala GABA-A receptors in morphine state-dependent memory. Life Sciences, 86(23-24), 887-93. [DOI:10.1016/j.lfs.2010.04.006] [PMID]

Reis, H. J., Guatimosim, C., Paquet, M., Santos, M., Ribeiro, F. M., \& Kummer, A. et al. (2009). Neuro-transmitters in the central nervous system \& their implication in learning and memory processes. Current Medicinal Chemistry, 16(7), 796-840. [D OI:10.2174/092986709787549271] [PMID]

Ren, X., Lutfy, K., Mangubat, M., Ferrini, M. G., Lee, M. L., \& Liu, Y., et al. (2013). Alterations in phosphorylated CREB expression in different brain regions following short-and longterm morphine exposure: Relationship to food intake. Journal of obesity, 2013. [DOI:10.1155/2013/764742] [PMID] [PMCID]
Rezayof, A., Darbandi, N., \& Zarrindast, M. R. (2008). Nicotinic acetylcholine receptors of the ventral tegmental area are involved in mediating morphine-state-dependent learning. Neurobiology of Learning and Memory, 90(1), 255-260. [DOI:10.1016/j.nlm.2008.03.004] [PMID]

Rezayof, A., Khajehpour, L., \& Zarrindast, M. (2009). The amygdala modulates morphine-induced state-dependent memory retrieval via muscarinic acetylcholine receptors. Neuroscience, 160(2), 255-63. [DOI:10.1016/j.neuroscience.2009.02.069] [PMID]

Rezayof, A., Razavi, S., Haeri-Rohani, A., Rassouli, Y., \& Zarrindast, M. R. (2007). GABAA receptors of hippocampal CA1 regions are involved in the acquisition and expression of morphine-induced place preference. European Neuropsychopharmacology, 17(1), 24-31. [DOI:10.1016/j.eut roneuro.2006.02.003] [PMID]

Rezayof, A., Zarrindast, M.-R., Sahraei, H., \& Haeri-Rohani, A. (2003). Involvement of dopamine receptors of the dorsal hippocampus on the acquisition and expression of morphine-induced place preference in rats. Journal of Psychopharmacology, 17(4), 415-23. [DOI:10.1177/0269881103174005] [PMID]

Rocha, L., Ackermann, R., Chugani, H., \& Engel Jr, J. (1994). Chronic pretreatment with naloxone modifies benzodiazepine receptor binding in amygdaloid kindled rats. Epilepsy Research, 17(2), 135-43. [DOI:10.1016/0920-1211(94)90013-2]

Rocha, L., Ackermann, R., Nassir, Y., Chugani, H., \& Engel Jr, J. (1993). Characterization of mu opioid receptor binding during amygdala kindling in rats and effects of chronic naloxone pretreatment: An autoradiographic study. Epilepsy Research 14(3), 195-208. [DOI:10.1016/0920-1211(93)90044-8]

Rocha, L., Cano, A., Cruz, C., Omana-Zapata, I., Villalobos, R., \& Maidment, N. (1999). Opioid peptide systems following a subconvulsant dose of pentylenetetrazol in rats. Epilepsy Research, 37(2), 141-50. [DOI:10.1016/S0920-1211(99)00056-X]

Rossato, J. I., Bevilaqua, L. R., Izquierdo, I., Medina, J. H., \& Cammarota, M. (2009). Dopamine controls persistence of long-term memory storage. Science, 325(5943), 1017-20.

Ruzicka, B. B., \& Jhamandas, K. (1991). Met-enkephalin release from slices of the rat striatum and globus pallidus: stimulation by excitatory amino acids. Journal of Pharmacology and Experimental Therapeutics, 257(3), 1025-33. http://citeseerx.ist. psu.edu/viewdoc/download?doi=10.1.1.968.7988\&re $\mathrm{p}=$ rep $1 \&$ type $=\mathrm{pdf}$

Schroeder, J., \& Schneider, J. (2002). GABA-opioid interactions in the globus pallidus:[D-Ala2]-Met-enkephalinamide attenuates potassium-evoked GABA release after nigrostriatal lesion. Journal of Neurochemistry, 82(3), 666-73. [DOI:10.1046/ j.1471-4159.2002.01010.x] [PMID]

Shaw, N., \& Webster, D. M. (1979). Disruption of taste aversion learning by pentylenetetrazol. Psychopharmacology, 66(2), 19598. [DOI:10.1007/BF00427630] [PMID]

Shimada, T., \& Yamagata, K. (2018). Pentylenetetrazole-induced kindling mouse model. Journal of Visualized Experiments, (136):e56573. [DOI:10.3791/56573] [PMID] [PMCID]

Siroosi, Sh., Manaheji, H., Dargahi, L., \& Daniali, S. (2015). Expression of spinal cord GABA transporter 1 in morphine-tolerant male Wistar rats. European Journal of Pharmacology, 767, 77-81. [DOI:10.1016/j.ejphar.2015.10.010] [PMID] 
Soares, D. C., Portela, J. L., Roos, D. H., Rodrigues, N. R., Gomes, K. K., \& Macedo, G. E. (2018). Treatment with Pentylenetetrazole (PTZ) and 4-aminopyridine (4-AP) differently affects survival, locomotor activity, and biochemical markers in Drosophila melanogaster. Molecular and Cellular Biochemistry, 442(1-2), 129-42. [DOI:10.1007/s11010-017-3198-3] [PMID]

Talavera, E., Oman, I., Asai, M., \& Condés-Lara, M. (1989). Regional brain IR-Met-, IR-Leu-enkephalin concentrations during progress and full electrical amygdaloid kindling. Brain Research, 485(1), 141-8. [DOI:10.1016/0006-8993(89)90675-6]

Vakili, A., Tayebi, K., Jafari, M., Zarrindast, M., \& Djahanguiri, B. (2006). Effect of ethanol on morphine state-dependent learning in the mouse: involvement of GABAergic, opioidergic and cholinergic systems. Alcohol and Alcoholism, 39(5), 42732. [DOI:10.1093/alcalc/agh084] [PMID]

Vindrola, O., Asai, M., Zubieta, M., \& Linares, G. (1983). Brain content of immunoreactive [Leu5] enkephalin and [Met5] enkephalin after pentylenetetrazol-induced convulsions. European Journal of Pharmacology, 90(1), 85-89. [DOI:10.1016/00142999(83)90216-9]

Vindrola, O., Briones, R., Asai, M., \& Fernández-Guardiola, A. (1981). Amygdaloid kindling enhances the enkephalin content in the rat brain. Neuroscience Letters, 21(1), 39-43. [DOI:10.1016/0304-3940(81)90054-9]

Viu, E., Zapata, A., Capdevila, J., Skolnick, P., \& Trullas, R. (2000). Glycine $B$ receptor antagonists and partial agonists prevent memory deficits in inhibitory avoidance learning. Neurobiology of Learning and Memory, 74(2), 146-60. [DOI:10.1006/ nlme.1999.3947] [PMID]

Wang, P., Wang, W.-P., Wang, H.-X., \& Fan, Y.-H. (2008). Impaired spatial learning related with decreased expression of calcium/calmodulin-dependent protein kinase IIa and cAMP-response element binding protein in the pentylenetetrazol-kindled rats. Brain Research, 1238, 108-17. [DOI:10.1016/j. brainres.2008.07.103] [PMID]

Xi, Z.-X., \& Stein, E. A. (1998). Nucleus accumbens dopamine release modulation by mesolimbic GABAA receptors-an in vivo electrochemical study. Brain Research, 798(1-2), 156-65. [DOI:10.1016/S0006-8993(98)00406-5]

Xi, Z. X., \& Stein, E. A. (2000). Increased mesolimbic GABA concentration blocks heroin self-administration in the rat. Journal of Pharmacology and Experimental Therapeutics, 294(2), 613-619. https://jpet.aspetjournals.org/content/294/2/613.short

Xi, Z. X., \& Stein, E. A. (2002). GABAergic mechanisms of opiate reinforcement. Alcohol and Alcoholism, 37(5), 485-94. [DOI:10.1093/alcalc/37.5.485] [PMID]

Zarrindast, M. R., Ahmadi, S., Haeri-Rohani, A., Rezayof, A., Jafari, M. R., \& Jafari-Sabet, M. (2004). GABAA receptors in the basolateral amygdala are involved in mediating morphine reward. Brain Research, 1006(1), 49-58. [DOI:10.1016/j. brainres.2003.12.048] [PMID]

Zarrindast, M. R., Bananej, M., Khalilzadeh, A., Fazli-Tabaei, S., Haeri-Rohani, A., \& Rezayof, A. (2006). Influence of intracerebroventricular administration of dopaminergic drugs on morphine state-dependent memory in the step-down passive avoidance test. Neurobiology of Learning and Memory, 86(3), 286-92. [DOI:10.1016/j.nlm.2006.04.002] [PMID]
Zarrindast, M. R., Farajzadeh, Z., Rostami, P., Rezayof, A., \& Nourjah, P. (2005). Involvement of the ventral tegmental area (VTA) in morphine-induced memory retention in morphinesensitized rats. Behavioural Brain Research, 163(1), 100-06. [DOI:10.1016/j.bbr.2005.04.006] [PMID]

Zarrindast, M.-R., Hoghooghi, V., \& Rezayof, A. (2008). Inhibition of morphine-induced amnesia in morphine-sensitized mice: involvement of dorsal hippocampal GABAergic receptors. Neuropharmacology, 54(3), 569-76. [DOI:10.1016/j.neuropp harm.2007.11.004] [PMID]

Zarrindast, M.-R., Jafari-Sabet, M., Rezayat, M., Djahanguiri, B., \& Rezayof, A. (2006). Involvement of nmda receptors in morphine state-dependent learning in mice. International Journal of Neuroscience, 116(6), 731-43. [DOI:10.1080/00207450600675068] [PMID]

Zarrindast, M.-R., \& Rezayof, A. (2004). Morphine state-dependent learning: Sensitization and interactions with dopamine receptors. European Journal of Pharmacology, 497(2), 197-204. [DOI:10.1016/j.ejphar.2004.06.041] [PMID]

Zarrindast, M. R., Ardjmand, A., Rezayof, A., \& Ahmadi, S. (2013). The time profile of morphine effect on different phases of inhibitory avoidance memory in rat. Archives of Iranian Medicine (AIM), 16(1). [PMID]

Zarrindast, M. R., Piri, M., Nasehi, M., \& Ebrahimi-Ghiri, M. (2012). Nitric oxide in the nucleus accumbens is involved in retrieval of inhibitory avoidance memory by nicotine. Pharmacology Biochemistry and Behavior, 101(1), 166-73. [DOI:10.1016/j. pbb.2011.11.010] [PMID]

Zhou, J. L., Lenck-Santini, P. P., \& Holmes, G. L. (2007). Postictal single-cell firing patterns in the hippocampus. Epilepsia, 48(4), 713-9. [DOI:10.1111/j.1528-1167.2006.00972.x] [PMID]

Zhou, J. L., Shatskikh, T. N., Liu, X., \& Holmes, G. L. (2007). Impaired single cell firing and long-term potentiation parallels memory impairment following recurrent seizures. European Journal of Neuroscience, 25(12), 3667-77. [DOI:10.1111/j.14609568.2007.05598.x] [PMID]

Zhu, W., \& Pan, Z. (2004). Synaptic properties and postsynaptic opioid effects in rat central amygdala neurons. Neuroscience, 127(4), 871-9. [DOI:10.1016/j.neuroscience.2004.05.043] [PMID]

Zubieta, M., Vindrola, O., Talavera, E., Asai, M., Massarini, A., \& Linares, G. (1985). Pentylenetetrazol-induced seizures produce an increased release of IR-Met-enkephalin from rat striatum in vitro. Brain Research, 360(1-2), 101-7. [DOI:10.1016/0006-8993(85)91225-9] 
This Page Intentionally Left Blank 